\title{
Theology: Still a queen of science in the post-modern era
}

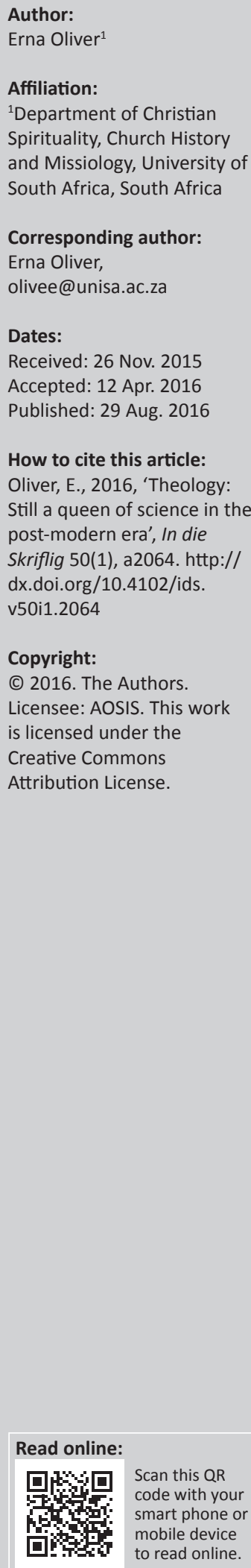

\begin{abstract}
Theology is just as relevant today as it was in the time of Aquinas who called theology 'the queen of science' although the knowledge-driven network society does not seem to be in agreement. By using the tools provided by the fourth revolution in the development of society, theology can, as part of the academic world of higher education that is supposed to lead society, strengthen ties with the past, seek explanations and solutions to current problems and produce guidelines for future investigation through multi- and interdisciplinary discourse. Theology can and should influence people to become positive change agents, re-shape the way in which the message of salvation is brought to the world in order to stay relevant in changing circumstances and be on the forefront of progressive transformation in society. This should be achieved through constant dialogue with other academic disciplines, the Church as institution and with society in general.
\end{abstract}

\section{Introduction}

Theology was already called the queen of science more than 800 years ago (after a claim made by Aquinas), but it seems as if the queen could lose her crown because of the influence of secularisation (understood as the absence of religion or the separation of Church and state or simply that religion is one option amongst many - Taylor 2007:3) on the one hand, and the move towards a technologybased, network society with its tendency of privatisation of religion on the other hand. Although secularisation is often seen as a 'subtraction' of religion from life, Taylor's (2007:22) view that faith and religion have become an option that could either be chosen or rejected, is more explanatory of the complexity and pluralistic nature of the issue. Opposed to Taylor's proposed adoption of the 'secular age', Miller (2008:4) suggests the use of the term 'religio-secular age' to emphasise the hybrid and multi faceted character of society, where religion and faith are still dominant parts of life but uncertain regarding their status in the public sphere.

This ambivalent position of the Christian religion is underlined by contrasts and conflicts. While secularisation is expanding, religious fundamentalism is also gaining momentum and influence (Emerson \& Hartman 2006:127-144) and it seems as if the influence of the Christian religion is far from becoming irrelevant. Christian faith is still influencing society and the following serves to underline this: the Bible is still one of the books that sells record numbers year after year. Books that focus on religious topics are one of the fastest growing segments in the publishing industry (Mertes n.d.:1) and the gospel music industry is alive and well. The Christian religion, through its passionate believers, managed to changed society for more than two thousand years; it has been responsible for changing attitudes towards women and children, the old and the marginalised, the sick and the poor. Christianity is also responsible for the invention of charity organisations, health care systems, several inventions, and even a stimulus for scientific research (cf. Hill 2005; Schmidt 2004; Sunshine 2009). New schools of theological thought are constantly developing. In Russia there is currently an attempt to introduce theology as a subject at universities. This is supported by the Russian Orthodox Church as '... an educated person should know the foundations of religion, because they are also foundations of culture' (Faustova 2012) and the history and culture of Russia have been based on Christianity for many centuries. However, all is not positive. Christianity also causes problems and conflict. Newspapers constantly report on events that are directly linked to the negative influence of religion on people all over the world, like the religious conflict in the Sudan and the lingering trouble linked to religion in Afganistan, Iraq, Pakistan, Israel and the escalating ISIS (Islamic State in Iraq and Syria) activity. Religion, including Christianity, was and still is responsible for numerous wars, persecution and suffering. It is clear that the place of religion, and in this case, Christianity, in the public domain deserves attention and research.

This article does not focus on Christianity in general, but more on the role that theology as an academic discipline can play in higher education to ensure a positive contribution to a society that 
is secular, and founded upon technology. It offers a broad, introductory overview to this subject and its possible use in the changing society. The intention is not to contribute to the debate in philosophical terms about the relevance of theology or its place in society. The goal is rather to look at the place of theology in higher education from the perspective of a church historian cum curriculum developer, who aims to provide a practical and workable proposal to implement theological training in higher education institutions to the benefit of both the students and society amidst calls for change in higher education and scepticism about the role and value of theological training. The article starts by summarising the historical development of theology as a contributor to the development of higher education. This serves to provide a short explanation why theology forms part of the traditional disciplines on higher education. The argument then advocates the current role that theology can play in higher education to promote effective education that could add to the valuable contribution graduates who studied theology or linked their studies to theology can provide to society.

\section{Setting of the current investigation}

The world we are living in is rapidly changing towards a technology-based, network society where the postmodern human tries to find new ways of expression, and different or creative answers to old questions that still need to be answered in order to show the meaning of life. Miller (2008:8) concludes correctly that ' $[a]$ round the world, we are, in effect, still fighting the battles of the European sixteenth, seventeenth, and eighteenth centuries - over revelation and reason, dogmatism and tolerance, absolutism and pluralism'. In South Africa these influences are also felt. In recent years a number of universities in South Africa closed their theology faculties and others felt the impact of rationalisation through the shrinking of faculties into departments (Buitendag 2014; Mouton 2008:432). This brings the question regarding theology's place in the public space on the African continent once again to the forefront.

The words of Taylor (2007:25) provide the underlying question to the current debates about the place and role of religion in society. He asks: '[W]hy was it virtually impossible not to believe in God in, say, 1500 in our Western society, while in 2000 many of us find this not only easy, but even inescapable?' He answers the question by proposing reform to Catholicism through claiming that, 'Christianity as a historical reality, wrought a transformation not in our speculative life, but in our practical life' (Rose 2014:9). I do not agree with his apologist way of adopting a secular status quo, but I do agree with Rose that Taylor's theology sees the relationship between humans and the world in such a way that it captures something richer and more intense than just a theoretical rational insight. It should focus on involvement and concern (Rose 2014:9). This connection and involvement with society and the world, is providing the niche position for theology to positively contribute to higher education, even in the technology-based, network society that we are currently moving into.
Another side of the secularisation debate was put on the table through the work of Agamben (2011:287) that argues that the rise of the administrative state is the completion of a development that started with the Greek form of government and developed through the Roman and Middle Ages, supplemented by the ever present need for power and glory. He points to the quest for power and glory that is also constantly disfiguring the Church as an institution (McAleer 2014:111). Theology as an academic subject in higher education cannot afford to seek power and glory but need to be humble and provide service (according to its true calling) and support in order for this discipline as an academic subject in higher education to stay a relevant and a sought after addition to qualifications.

Harrison (2009) challenges the perception that the development of science coincided with the triumph of reason over religion. He argues that theological issues still remain important in contexts such as education, epistemology and philosophy, all of which are influencing science and society in general. This argument set theology up for providing interdisciplinary support and development which should be a major focus point of academic programme development in theology at higher education institutions. Some suggestions and examples of how this could be carried out, will be provided in the second part of this article.

It is important to note that there were two assumptions with which this research was conducted. Most importantly, the research was carried out from a Christian point of view and could therefore not be labelled unbiased or neutral. It is assumed that a person's religion or absence of religion shapes and affects every aspect of that person's life, including his and/or her profession and position in society. This is not to say that a person who is a Muslim or Hindu or Buddhist would do a laboratory experiment differently from the way a Christian would do it, but to confirm the presumption that science is not the only measure of reality or truth and that even science could do with a spiritual compass or conscience.

On the other hand, it should also be acknowledged that faith, religion, and spirituality are not static. These concepts change constantly and people's perceptions and interpretations of these concepts also change with time, depending on their circumstances and even their age. Therefore, it is important to keep in mind that faith as a concept is also ambivalent and that this aspect of our lives needs constant development and adjustment to stay relevant and in touch with the world we inhabit to be able to have a formative influence in our lives. This is also applicable to theology as an academic discipline within the changing and challenging environment of the 21st century.

It is with these statements in mind that this article argues that religion, and in this case, theology, can and must interact with other sciences and with society. Secularisation, however it is defined, nor the privatisation of religion and the challenges presented by the technology-based, network 
society, should cause theology to shy away from discourse and interaction on all levels of society. In the past the traditional sciences such as law, medicine and cosmology were in constant dialogue with theology. This dialogue should be kept open and alive. Theology should also seek other opportunities to interact with academia, and society. Only recently theology realised that it should speak out and actively be involved with issues relating to the earth and its sustainability (Lowdermilk 1968; White 1967:1203-1207). There are also numerous other areas where the voice of theology could and should be heard.

A short summary of the history of theology as the queen of science will demonstrate the outline of this investigation. The background information is followed by short references to the development of universities to showcase the major role that theology played. The focus then shifts to a few short notes regarding the crisis that the development of the network society is currently causing for theology and higher education in general. By providing examples of the influence that theology has on society through referring to the so-called three publics of David Tracy (2002:13-22) and presented by Elna Mouton (2008:437), the position of theology and its ongoing task in society is explained and advocated. This broad overview can stimulate academics responsible for teaching theology at higher education institutions to consider exploring possible alternatives for the traditional ways, and take up the challenge to broaden the horizons of theology into actively becoming involved with interdisciplinary education and research on the one hand and also to ensure that graduates become positive agents of change (cf. Oliver 2013:7).

\section{The history of theology as queen of science}

Thomas Aquinas described theology as the queen of science in his great work Summa Theologica written between 1265 and 1274. He made this observation from his own perspective and worldview and his epistemology differs to a large extent from the paradigms we have today. However, we must keep in mind that, just as today, the world in which he wrote was also subjected to turbulence and full of unexpected changes. There were wars and famine and natural disasters threatening society and also intellectual or academic challenges. One of these was the shift during the High Middle Ages (1000 to 1300) from a Platonic to an Aristotelian world view after the rediscovery of the works of Aristotle (Armstrong 2013). For Augustine, who argued with a neo-Platonic view, science was anything that has to do with knowledge of the temporal world and as the Bible as the source of all truth was used as the overarching standard for all learning, theology became the standard by which scholarship of the day had to abide (Armstrong 2013). By the 12th century, however, Aristotle's dialectic method of thesis, antithesis and synthesis was used in theology and Thomas Aquinas became the synthesiser between Aristotle and Augustine (Armstrong 2013), thus making the claim that theology is a queen of science, an important statement that influenced the way theology saw its place in education and higher education in the centuries to come.
However, religion and theology are often seen as controversial subjects and therefore there are those who want the crown to be removed from theology (cf. Loughlin 2009:221-240). An early voice of objection came from Baron d'Holbach, the French revolution atheist, who claimed in 1770 that there was no place for theology at a university (Wilkinson 2007), while Stephen Hawking (1998) states that physics indeed seized theology's crown, by taking over the role of the discipline that provides answers to important research questions. These questions centre on who we are and why we exist. Assigning the task of providing answers to science rather than to theology is an active attempt to persuade theology to abdicate and leave the palace that she helped to design and build. The palace that is referred to here is the university as an academic institution. But theology is not that keen on leaving. Before moving to the reasons why theology needs to stay on the throne and in the palace, a few short notes on the development of universities could help to emphasise the influence religion and theology had on the establishment and development of these institutions in society.

\section{The development of universities}

Although there is no general agreement on this issue, it could be said that the worlds' oldest surviving university is the University of Nanjing in China, founded around 258 BC. Because this university did not issue formal degrees before 1888 , it is not recognised as the oldest university. According to the Guinness book of records, the oldest continuouslyoperating degree-granting university in the world is the University of Karueein in Fez, Morocco (Guinnessworldrecords. com). It was founded in $859 \mathrm{AD}$ by a woman called Fatima al-Fihri. It was originally a mosque and religion was the main subject taught. Mathematics, physics, chemistry, and foreign languages were introduced only in 1957 at this university.

The world's second oldest university is also to be found on the African continent, in Egypt. The Al Azhar University also focuses on an Islamic religious syllabus. The University of Baghdad in Iran (one of the prestigious Al Nizamiyya schools) was established in 1065 and only by the end of that century European universities such as those in Bologna, Paris, Oxford, Modena and Cambridge were developed.

The University of Bologna was the first European university (1088) and it developed, like many others, from monastery and cathedral schools (Boeree 2000). Haskins (1957) and Rashdall (1936) wrote fascinating histories on the rise of universities and the major role that theology played. However, this is beyond the focus of this investigation and the undermentioned reference to the development of the University of Paris is particularly made to show the influence that theology and influential theologians had in the construction of the university as an institution.

The establishment of the University of Paris, which played a major role in the development of the traditional university with the four basic faculties of Arts, Law, Medicine and Theology was a direct result of theological intervention in 
education. It developed from a cathedral school into a university when Pope Gregory VII gave instruction to establish schools and promote formal education in 1079. A product of this cathedral school, Peter Abelard did much to expand the idea of universities in general (Boeree 2000). Thomas Aquinas, the theologian who was the first to refer to theology as the queen of science, in his later years mainly taught in Paris where his explanation of the relationship between reason and faith helped scientists who accepted Aristotle's naturalistic philosophy, to remain Christians. He did this through the development of a synthesis between faith and reason - God is the origin of both nature and revelation, both reason and faith and therefore they cannot be in conflict with each other - all truth is God's truth: faith completes reason and reason upholds faith (Armstrong 2013).

Traditionally, universities rely heavily on printed material. This is the result of the embracing of the third revolution in the development of society to which the attention is now turned in order to show why universities in general and theology in particular, currently find themselves in an identity crisis.

\section{The current crisis of the fourth revolution}

The reason why universities, and therefore also the academic practice of theology, are no longer deemed necessary in postmodern society, is explained by Warschauer and Matuchniak (2010:179). According to them the development of society is characterised by four great revolutions. The first revolution was the development of language, and the second came through the development of writing. The third major change in the development of society came through the printing press and the current revolution that we are experiencing is living in a network society.

Not only people are affected. Institutions like universities and churches also have to adapt and make major changes in order to stay relevant in the postmodern society. Universities built their empires on the results of the third revolution and therefore need to make a radical paradigm shift if they are to survive the onslaught of the fourth revolution. It is not so much the 'what' (content) that is taught that needs to change but the 'how' (means through which teaching and learning take place) that is in need of change (Bates 2010:22). The basic content taught in theology is more or less set, but there are constant developments of new theologies and new or different interpretations of events and theories in the light of changing perspectives and insight that need research and inclusion in theological curricula. There is also a need to transfer the good news message into changing circumstances and settings in order for them to stay applicable for people living in the postmodern world. Although the issue of how the change from the era of the printing press (third revolution) to a network society (fourth and current revolution) impacts on the future of universities should be investigated further, it is beyond the scope of the current research. However, more can be said to summarise the current controversy regarding the place of universities and therefore also the place of theology in society.

Deem (2012) states that contemporary debates regarding the purpose of universities typically fall into three categories. In the first place there are debates that focus on what defines 'world-class' global, and elite universities (Deem 2012:108). The controversy here is mainly about research outputs, how academic research is managed and the recruitment of international students and staff members to aid in the quest for advanced research. The second group of debates centers on the issue of 'entrepreneurial' universities and reflect the 1990s pre-occupation with the way in which universities shifted from traditional academic concerns toward the pursuit of additional funding through applied research and various commercialised activities (Deem 2012:109). In the last place there are debates that focus on the question of what universities have become (and de facto what they should or should not become). Here the discourse is often focused on teaching and research as core activities in the academy (Peters 2007). Some see the demise of the 'traditional' university and its disciplines as a solution, but these views tend to overlook the fact that the range of desirable purposes for universities is expanding beyond teaching and research as conventionally conceived (Deem 2012:110).

Furthermore, there is a strong tension between the notion that higher education is essentially an arm of industry and commerce and the notion that higher education is a social and developmental activity. Gumport (2000:70-71) is convinced that universities '... must preserve a broader range of social functions that include such essential educational legacies as the cultivation of citizenship, the preservation of cultural heritage(s), and the formation of individual character and habits of mind'. This perspective could directly be linked to the desired outcome of graduates to be positive agents of change in their communities which fits in with the aim and goal of theological education provision at higher education institutions.

Although it is clear that there is a need for a paradigm shift on the role and task of universities in society, it should also be clear that, if carried out correctly, universities and theology should be able to support society and still play a major role in the postmodern world. Technology should be embraced to enhance and promote effective education (cf. Oliver 2014). Higher education, and more specifically theology, should also enhance life-long learning through student-centered teaching, blended learning and transformative assessment (Oliver 2016). Graduates should be able to become positive agents of change in their respective communities as a result of the alteration in the aim of education that focus more on capacities and capabilities than on knowledge hoarding (Canning \& Callan 2010:71-82) because the one-size-fits-all approach that was followed during the industrial era of mass education is fading. However, the ways and paths that theological education could follow in order to stay relevant 
in the technology-based society, is not the main focus point here.

This article aims to provide a possible answer to the question of how to adapt to the new circumstances brought about by secularisation and privatisation by reasoning why and how theology could still be seen as the queen of science by placing her in the centre of research and dialogue with other sciences and society. However, it is not possible to fully and broadly discuss an issue of this format in one article. Therefore, only an introductory overview of some important issues are highlighted below.

\section{Why theology is still a queen of science}

Earlier it was stated that Christianity has the ability to bring about major changes in society. Theology is the means through which academics and society strengthen their ties with these changes and influences from the past, seek explanations and answers to current issues and problems and produce guidelines for future research and investigation. Buitendag (2014) is correct when saying that African theologians who are currently struggling with issues such as secularisation, the influence of the network society on higher education and the identity crisis that theology is experiencing, can take heart. There is no need to go through the same trauma in this regard as Europe and America. There is a definite need for the guiding voice of theology, midway between the extremes of sectarianism and secularism through scientific, faith based theology (McGrath 2004) to contribute to the better understanding of and contributing to sustainability of life in our unique circumstances.

Some of the questions that theologians and Christians in general grappled with in medieval times are still unresolved. These issues are stimulating academic thought and research, both in theology and in other disciplines, to this day. Current debates and research problems are often linked to these 'old' issues.

Mouton (2008:437) provides a graph of the three publics of David Tracy (2002:13-22). The three spheres are society, academia and church. Theology forms the epicentre of the interrelated and interdependent loops of these three circles and therefore theology has a specific task to perform in each of the three outer circles; that of the church, society and academic life. Through the use of a few examples it will be explained how and why theology is relevant and important in these general areas of our postmodern lives. These examples will focus on the traditional university groupings of theology, law, cosmology and medicine.

\section{Theological issues}

For a very long time academic and public debates centred on theological issues such as immortality and original $\sin$ (Rubin \& Simons 2010:383). Research and dialogue regarding issues such as the conception and birth of Jesus or the questions around the resurrection are also topics that remained on the table for centuries. The discourse on miracles did not only re-occur in the sphere of the Church but was also debated in academic circles and in society. Currently, every now and then a media storm erupts about miracle healings when a sport hero or other well-known person becomes terminally ill and seeks help from spiritual healers. See for instance the cases of rugby players Ruben Kruger (Daily Independent 5 February 2010) and more recently Joost van der Westhuizen (Cox 2013). It is the task and calling of theology to speak to and enlighten these issues for both the Church and the community.

\section{Medical issues}

Theology and the medical profession are in constant dialogue. It seems as if medical-ethical issues increase daily. The prolongation of life on the one hand and the termination of life by choice on the other hand through medical interventions seems to be fuelling this never-ending debate. Issues such as abortion, suicide, euthanasia and genocide likewise, come a long way from biblical times and are still with us today. Although the use of antibiotics and blood transfusions are common today, both these aspects caused problems on which endless debates have been built decades ago. All of these debates and issues directly involve theology.

There are new medical-related issues emerging constantly on which theology needs to provide answers and guidelines both to the Church and to society in general. Terminal illnesses such as cancer require constant research and often ethical issues develop that are in need of clarification regarding the research and treatment of this illness. HIV and AIDS regularly spark controversy, debate and dialogue regarding research and the practicalities of how to deal with these issues in a work environment or in personal relationships as well as the duty of the Church and Christians towards people affected by the pandemic. Issues that theology is currently required to provide information and guidelines on include the use of stem cells, cloning and DNA manipulation, to name just a few major and more generally known issues. It seems as if there should be constant interaction between the medical profession and theology.

\section{Juridical issues}

A number of the large world religions are built on laws. Christianity combined and built upon the laws of Judaism. Throughout the Christian era, theology had a huge influence on the development and implementation of laws and customs (such as swearing on the Bible), both inside the Church (canon law) and in society in general. New 'theologies' such as Black Liberation theology, Feminist theology and the Social Gospel were developed to provide opportunities for theology to speak out and aid in the fight for justice. The effect and success that these developments had and in some cases still have, indicates that theology does have strong persuasive powers towards renewal and transformation in society. There is a constant need for the development of new 
contextual theologies that speak to people and societies in their current situations and addressing their problems constructively and positively. Contextual theology can act as the conscience of society, state, Church and individuals (Kealotswe 2013).

Ethical issues are similarly prominent in juridical issues. One topic that shows a thread through Christian history is the debate around the free will of humans. Together with this, also running through the lines of history, are issues around war and peace from a Christian perspective. More recently concerns about slavery developed into disputes around human rights. Another issue that often involves Christian ethics is the debate around the use of the death penalty. Theologians are expected to comment and provide insight on controversial matters such as the difference between terrorists and freedom fighters (which usually depends on the side they are investigated from). In the South African context the issues of corruption, crime, bribery and racism are all important problems to which theology should voice its objections publicly and at all levels of society. It seems natural that theology should keep an open communication line with the juridical systems in the country.

\section{Cosmology}

In medieval times astrological and geographical subjects formed part of the general curriculum taught at universities. Major shifts in world views and the development of science were brought about by crucial findings about the fallacy of the earth being flat and the centrepiece of the universe. Theology played a major role in those discourses (although, admittedly, not always positive and constructive). The focus on our place in the universe continues today with the attention on earth-keeping issues such as global warming, endangered species and the possibility of life on other planets. In all these issues theology can and must play a significant role.

\section{How theology can manage her position}

Richardson (2005:556-557) predicts a 'freeway' to the future for theology by using the prefix 'inter-' as a philosophical framework. According to him, theology will flourish if it ensures that it is inter-denominational, inter-faith, intercultural, international, interdisciplinary and inter-active. Currently, a number of theology courses and programmes are developed to expand and incorporate these interrelationships. An example of a course developed with the 'inter-' framework in mind, is the second year course on world Christianity and ecumenism, provided by the University of South Africa as part of the BTh programme. This course promotes inter-denominational, inter-faith and inter-cultural discussions, actions and debates. The course was designed in such a way that it provides students with choices and flexibility which enables them to link with other courses in other disciplines they are taking as well as with the current problems and issues they are experiencing in their communities. The course challenges and tasks students to become positive agents of change and to transfer their knowledge and insight to those around them (cf. Oliver 2013:1-7). Examples of other theology courses that use the 'inter-' links are those focused on gender studies, business ethics, decolonisation, ecology, race and religion, theological anthropology and Africanisation, to name just a few.

All of these inter-links are important for the theological disciplines and they can also help to link the different disciplines with each other. More importantly they will ensure a link between theology and other academic disciplines as was mentioned and explained above, as well as providing guidance for society and the Church in matters of concern and current problems. It is clear that in order for theology as academic discipline to have a positive and productive influence in the current and forthcoming society, this issue of 'inter-links' and relationships with other disciplines and aspects of life must be explored and researched and implemented to a much larger extent. Theology will then once again be in its rightful place: in the public domain, positively influencing and changing people and transforming structures.

\section{Conclusion}

Theology and religion is just as relevant today as it was in the time of Aquinas. Although society is currently experiencing the onslaught of secularisation, and theology finds itself in a crisis because of the link that theology has with higher education as well as the fourth revolution that is influencing the structures of the third revolution upon which theology as academic field was firmly built, these difficult and uncertain circumstances are no reason for despair or silence. Theology can and should, as it did during the previous revolution, embrace the opportunities and new developments provided by the rapid development of technology to seek new methods to proclaim the Gospel to all and positively alter peoples' perceptions, practices and behaviour. Theology as the epicentre of the Church, academic life and society (Mouton 2008; Tracy 2002), should use the 'inter-link' framework of Richardson (2005) to practice scientific theology (McGrath 2004) to re-shape the way in which the message of salvation is brought, and to remain a prominent partner in discourse and the search for answers and solutions about important issues in life.

This could be carried out if theology as academic discipline:

- Adapts the proposed philosophical 'inter-linked' framework, implementing it within the three influential spheres of academic life, society and the Church by instigating renewal, change and transformation in the lives of people living in the network society. This framework can be used to discuss and provide guidance on academic as well as practical issues as explained through the examples above.

- Practise scientific theology to constantly develop new theologies and to provide meaningful answers to important questions to address the issues put on the table by the secular, knowledge-driven society. 
- Stay in the epicentre of society, academia and Church to actively promote and bring about change, renewal and transformation in individuals' lives and in societal structures in accordance with the positive changes that were brought about during the last two thousand years.

This is the current task of theology in the public space and therefore theology should be recognised and respected for this major transformative role she has to play in society.

\section{Acknowledgements Competing interests}

The author declares that she has no financial or personal relationships which may have inappropriately influenced her in writing this article.

\section{References}

Agamben, G., 2011, The Kingdom and the Glory: For a Theological Genealogy of Economy and Government, Stanford University Press, Stanford, CA.

Armstrong, C., 2013, How theology became the Queen of the Sciences (and how Aristotle helped us see that 'all truth is God's truth'), viewed 05 September 2013 from http:// gratefultothedead.wordpress.com/2013/09/05/how-theology-became-the-queenof-the-sciences-and-how-aristotle-helped-us-see-that-all-thruth-is-gods-truth/

Bates, T., 2010, 'New challenges for universities: Why they must change', in U-D. Ehlers \& D. Schneckenberg (eds.), Changing cultures in higher education. Moving ahead to future learning, pp. 15-25, Springer, Heidelberg.

Boeree, C.G., 2000, The Middle Ages, viewed 13 September 2013, from http:// webspace.ship.edu/cgboer/middleages.html

Buitendag, J., 2014, 'Between the Scylla and the Charybdis: Theological education in the 21st century in Africa', HTS Theological Studies 70(1), Art. \#2855, 5 p. http:// dx.doi.org/10.4102/hts.v70i1.2855

Canning, N. \& Callan, S., 2010, 'Heutagogy: Spirals of reflection to empower learners in higher education', Reflective practice: International and multidisciplinary perspectives 11(1), 71-82, http://dx.doi.org/10.1080/14623940903500069

Cox, A., 2013, Doctors reject Joost's cure claim, viewed 10 February 2015, from http:// www.iol.co.za/news/south-africa/gauteng/doctors-reject-joost-s-cureclaim-1.1576763\#.UnEA2_mnrnE

Daily Independent, 5 Febr. 2010, Nigeria: Cancer undoes Joshua's healing 10 years after, viewed 10 February 2014 from http://allafrica.com/stories/201002081113. htm

Deem, R., 2012, 'The twenty-first-Century University: dilemmas of leadership and organizational futures', in A.R. Nelson \& I.P. Wei (eds.), The global university. Past, present and future perspectives, pp. 105-129, Macmillan, New York.

Emerson, M.O. \& Hartman, D., 2006, 'The rise of religious fundamentalism', Annual review of Sociology 32, 127-144. http://dx.doi.org/10.1146/annurev.soc.32. 061604.123141

Faustova, M., 2012, 'Theology in secular universities - pros and cons', Voice of Russia, viewed 08 August 2013, from http://www. pravoslavie.ru/english/57869.htm

Guinnessworldrecords.com, Oldest University, viewed 10 August 2013, from http:// www.guinnessworldrecords.com/world-records/3000/oldest-university

Gumport, P., 2000, 'Academic restructuring: Organizational change and institutional imperatives', Higher Education 39(1), 67-91. http://dx.doi.org/10.1023/A:100 3859026301

Harrison, P., 2009, The fall of Man and the Foundations of Science, Cambridge University Press, Cambridge.
Haskins, C.H., 1957, The rise of Universities, Cornell University Press, New York.

Hawking, S., 1998, A Brief history of Time, Bantam, New York.

Hill, J., 2005, What has Christianity ever done for us? How it shaped the modern world, InterVarsity Press, Downers Grove, IL.

Kealotswe, O.N., 2013, 'Bringing theology to the main domain: Theology and politics', keynote address at the 3 rd colloquium conference of the Voice and Voicelessness, keynote address at the 3rd colloquium con
University of Botswana, 23-25 September.

Loughlin, G., 2009, 'Theology in the University', in I. Ker \& T. Merrigan (eds.), The Cambridge Companion to John Henry Newman, pp. 221-240, Cambridge University Press, Cambridge.

Lowdermilk, W.C., 1968, Palestine, Land of promise, Greenwood, New York.

McAleer, G.J., 2014, 'A review of "The Kingdom and the Glory: For a Theologica Genealogy of Economy and Government" and "Adam Smith as Theologian", Perspectives on Political Science 43(2), 109-111. http://dx.doi.org/10.1080/1045 7097.2013.782767

McGrath, A.E., 2004, The science of God: An introduction to scientific theology, Clark, London.

Mertes, K., n.d., The queen of science: Indexing theology and disciplines related to religion, viewed 31 July 2013, from www.katemertes.com/theologyandreli gionindexing.pdf

Miller, J., 2008, 'What secular age?', International Journal of Politics, Culture and Society, viewed 12 July 2013, from http://link.springer.com/article/10.1007/ s10767-008-9037-5/fulltext.html

Mouton, E., 2008. 'Christian theology at the University: On the threshold or in the margin?', Hervormde Teologiese Studies 64(1), 431-445. http://dx.doi.org/ 10.4102/hts.v64i1.21

Oliver, E., 2013. 'Teaching open distance learning undergraduates in Theology to become effective change agents', Verbum et Ecclesia 34(1), Art. \#845, 7 p. http:// dx.doi.org/10.4102/ve.v34i1.845

Oliver, E., 2014, 'Theological education with the help of technology', HTS Teologiese studies/Theological Studies 70(1), Art. \#2643, 7 p. http://dx.doi.org/10.4102/hts. v70i1.2643

Oliver, E., 2016, 'The triangle of effective education: student-centred teaching, blended learning, transformative assessment', paper to be presented at the International Journal of Arts and Sciences conference at the Ryerson University in Toronto, Canada, 31 May to 3 June 2016.

Peters, M., 2007, Remaining the University in the global era, viewed 12 July 2013, from http://recordings.wun.ac.U.K./id/2007/id20070525/index.html

Rashdall, H., 1936, The universities of Europe in the middle ages. Volume 1: SalernoBologna-Paris, Oxford University Press, London.

Richardson, N., 2005, 'The future of South African theology: scanning the road ahead', Scriptura 89, 550-562. http://dx.doi.org/10.7833/89-0-1037

Rose, M., 2014. 'Tayloring Christianity. Charles Taylor is a theologian of the secular status quo.' First Things, viewed 4 April 2016, from http://www.firstthings.com/ article/2014/tayloring-christianity

Rubin, M. \& Simons, W., 2010, Faith and the intellectuals. The Cambridge history of Christianity, 327-404. http://dx.doi.org/10.1017/CHOL9780521811064.026.

Schmidt, A.J., 2004, How Christianity changed the world, Zondervan, Grand Rapids, MI.

Sunshine, G.S., 2009, Why you think the way you do: the story of western worldviews from Rome to home, Zondervan, Grand Rapids, MI.

Taylor, C., 2007, A secular age, The Belknap Press of Harvard University Press, Cambridge.

Tracy, D., 2002, 'On theological education: A reflection', in R.L. Petersen \& N.M. Rourke (eds.), Theological literacy for the twenty-first century, pp. 13-22, Eerdmans, Grand Rapids, ML.

Warschauer, M. \& Matuchniak, T., 2010, 'New technology and digital worlds: Analyzing evidence of equity in access, use, and outcomes', Review of Research Education 34, 179-224. http://dx.doi.org/10.3102/0091732X09349791

White, L., 1967, 'The historical Roots of our ecologic crisis', Science 155(3767), 1203-1207. http://dx.doi.org/10.1126/science.155.3767.1203

Wilkinson, S., 2007, The system of nature by Baron D'Holbach, translated from the original French, viewed 12 July 2013, from http://www.philosophy-index.com/dholbach/system-nature/ 